\title{
Fall of Monuments as a Tool for Social Change
}

\author{
N. Wijegoonawardana \\ Senior Lecturer, Department of History, Faculty of Arts, \\ University of Colombo \\ *Corresponding author: N. Wijegoonawardana, Email: nirmaliwijegoonawardana@gmail.com
}

\begin{abstract}
This paper will explore a different form of global socio-political protest, which spread in cities worldwide and was characterized by the pulling down of certain monuments in public space. This investigates how the fall of monuments operates as a tool for political resistance against marginalization, discrimination and exclusion, a binding factor for democracy and social justice, and as a means of dealing with contested heritage. Protesters referring to themselves as 'Fallist,' common across the world, raise concerns about race, identity, position and recognition in society. They choose pulling down monuments as a tool through which they demand addressing of socio-political injustices. In consideration of the above this study employs the methodological application of qualitative exploratory design as well as analyzing contemporary cases of street protest surrounding the pulling down of monuments from different geographic and socio -political contexts, including South Africa, United States and the United Kingdom. This paper further argues that the pulling down of monuments is thus not merely about contesting the past; it also operates as a tool for inquiring, critiquing, and changing the present.
\end{abstract}

Key words: Monuments, Fallist, Injustice, Heritage and Social change

\section{Introduction}

Chief administrator of the Roman the emperor Sejanus was executed and suffered after death for his crimes through the punishment of Damnatio memoriae wherein all of his statues and his name was removed from public records. This was standard Roman legal procedure at the time and involved the erasure of public figures from all public memory (Presciuttini, 2017). The Pharaohs of Egypt were no exception, their chose to erase the names of their predecessors from temples and statues in an attempt to dictate history. 
The pulling down of British Imperialist Statues in 1776 in an attempt to mark the independence of the United States is a further example of adopting such practices to signify a political change. Another poignant example would be the Tsarist monuments in the October Revolution of 1917. Such examples portray how by pulling down and removing public monuments served as a mechanism of accepting fallen political regimes and a clear political disempowerment of such fallen regime. Furthermore, recent destruction of public monuments explains that to erase condemned individuals from public remembrance and to express society`s disapproval of their actions.

Ranging from the execution of Sejanus to the October Revolution, imagebreaking has served as a forceful example of erasure of historical memory or condemnation of regimes. Such acts must not be considered to be mere acts of destruction, rather events of 'Iconoclash' as described by Latour (2000), where the creation of new images can be construed to be impactful means of social change.

The protesters identifying themselves as the 'Fallists' across the world, where they choose to target statues and monuments placed in public spaces as a mechanism through which they demand to address socio-political injustices. Fallists in the United States perceive the presence of a monument as an act of derogation against African Americans because in their opinion monuments of such nature only serve to glorify the colonial ruler that was instrumental in white supremacy which was founded upon discrimination, exploitation and violence against African Americans (Marshall 2017; Knudsen \& Andersen 2019).

This paper will be structured in the manner stipulated herein. An apt mechanism through which the impact of certain events has on the sociopolitical spheres of the world first require the analysis of existing literature, thus this paper will analyze the existing literature of thought on the fall of monuments pursuant to which an analysis of existing case studies will be carried out. 


\section{Socio-political causes for pulling down monuments}

The effects of defacing and pulling down of monuments and its impact on the socio-political sphere have long being emphasized by scholars from a wide range of disciplines.

Gambani (2013) harps on the impact of the destruction of objects and misuse of works of art on the transformation of societies and stipulated that sticking to the notion of the present world being a representation of some sort of goal of mankind and the consideration of such destruction of monuments as a temporary relapse into the past, is one way of looking at the world. Furthermore, he stipulates that the events of violence to monuments, works of art, objects and statues may be perceived as the importance society places on symbolism. The key place awarded to identities in contrast to territories in modern conflicts is a key contributory factor towards the destruction of culturally significant objects.

Furthermore, he theorized that the destruction of statues in public spaces can be perceived as a form of political iconoclasm (Gambioni, 2013), and can also be portrayed as the intentional violence against urban landmarks that represent a particular political doctrine, ideology or authority. To such effect triumphal gates, victory columns, statues and other forms of art create part of a political iconography, that establish and portray the intentions of state governments, political leaders that enable the establishment of political power thus enabling the formation of a particular social order and hierarchy. Hobsbawm (1983), on the other hand, refers to such practices as "Invented Traditions" wherein he claims that monuments, statues are an embodiment of the past and only serve to reshape the present ${ }^{\mathrm{i}}$.

Barthes (2001) also adds through his most popular works of Mythologies by elucidating the depth of a front cover from the Paris Match Edition no. 326, of July 1955, which portrays a young black soldier in French uniform. Barthes stipulates that the signifier in this image, the saluting soldier offers no additional information of the soldier`s life. However, he argues that the selection of such an image for the front cover is to symbolize happenings much greater than the young man himself. Instead, the image portrays the French ideology of what it means to be French and what it means to be in the military encompassing in such image the ethnic diversity, thus sending a message to 
the world about France and its citizens. The placing and selection of the image does not necessarily perpetuate that France is a great empire and that all her sons live in the absence of color discrimination and faithfully serve under her flag, rather it portrays the myth of devotion to rule. Such myths exist in the current context and has like in previous occasions led to socio-political unrest, where Fallists attempt to debunk such myths by resorting to the destruction of monuments that serve as physical embodiments of myths.

Macdonald (2010) illustrates, in the post-war setting, the devastation of landmarks, likewise connections to the idea of managing 'troublesome legacy' or 'spots of agony and disgrace' troublesome legacy' as the wonder of countries or different groups freely flagging and recognizing past abominations that they committed and for which they are embarrassed. It is contended that such urban legacy 'harms' since it exemplifies scandalous pasts that have the ability to communicate the aggregate injury or shame of a social gathering and make the justification for nonstop political pressure and debates (Macdonald 2010).

Bevan (2007) argues that, memories, history and identity are attached to architecture and place. When it comes to war and conflict, the demolition of monuments and heritage in cities has been categorized as 'memorycide' (Bevan 2007; Riedlmayer 1995), which is speculated as the 'killing of memory' embodied in monuments, historic buildings, open spaces and urban quarters.

Gambioni (2013) also clarifies that the act of vandalizing monuments although may seem random at the time is in fact deliberate and calculated and aides in abolishing both the icon and the group of values such icon represented. Such political iconoclasm he claims has in previous instances successfully marked political shifts. Finally, Bredekamp (2017) elucidates that, in an attempt to justify a new social era, supporters of such new regime tend to choose monuments as a means of demonstrating political and societal change.

In view of the above, it is apparent that the causes for the pulling down and defacing of monuments serve as a means of relapsing to the past and although such acts may seem random at the time it is in fact intentional and serve also as a means of erasing memory which society or a part of society no longer accepts. 


\section{Narratives of removal and pulling down monuments}

Several case studies depict the increase in the pulling down and removal of monuments on the basis that such monuments represent a racist past and in certain instances such monuments serve as a means of idolization of white supremacy.

In 2017, New Orleans of the United States in the frontline of cities fighting white supremacy, it was manifested in monuments to the Confederate Generals Robert E. Lee and P. G. T. Beauregard, President of the Confederacy Jefferson Davis, and the 'Battle of Liberty Place' pillar. South Carolina had removed the Confederate flag from its statehouse and Memphis had made plans to relocate a Confederate monument there, but no other city had taken down, in swift succession, four prominent monuments to slaveholders, Confederates, and post-Civil War white supremacist violence.

On $19^{\text {th }}$ May 2017, crowds gathered to watch the careful dislodging of a sixteen-foot statue of Confederate General Robert. E. Lee from atop its 70-foot column and base at the centre of Lee Circle in downtown New Orleans, where it had stood for 133 years. For those who had been advocating removal of New Orleans's monuments to proslavery Confederates, Lee's fall was long overdue and cause for celebration. Although the city has yet to rename the traffic roundabout where the Lee statute once stood, among activists and monument protesters it acquired a new name when it was clear the statue would come down, 'Free Circle.' (Mitchell, 2020). Lee was the last of four prominent monuments removed in 2017. After a series of public hearings, City Council approval, and the defeat of several court challenges, the legal determination that the monuments were 'public nuisances' allowed for their removal (Wendland 2017).

On $9^{\text {th }}$ April 2015, the University of Cape Town, South Africa removed a statue commemorating the $19^{\text {th }}$ century British imperialist Cecil Rhodes. This was the culmination of a month-long campaign by both students and academics as part of the 'Rhodes Must Fall' movement, which argued that Rhodes was more than just a symbol of past oppression that he represented institutional racism which continues to exist within the university. Shepherd (2020) conceptualizes the sculpture's fall as an incredible emblematic act that holds the possibility to change the profoundly isolated South African culture 
to the better. At Oxford University, a campaign began for the removal of a statue of Rhodes at Oriel College, with supporters observing that any steps to address the lack of black and minority students and lecturers at the institution were undermined by the monument (Chigudu, 2020). For supporters, the Rhodes Must Fall campaign, "operates on the premise that these present discrepancies are rooted in history, and the present and the past must, together, be critically engaged with. The Rhodes Must Fall in Oxford campaign is led by black and minority ethnic students ${ }^{\mathrm{ii}}$.

In the United Kingdom the people who erected Edward Colston's statue in Bristol in the late $19^{\text {th }}$ Century decided their version of this man's history was more palatable and more valid. It was his philanthropy that won the day, not his slave trading. But a new generation isn't willing to absolve Colston any longer. His statue was pulled down by the protesters in Bristol, after pulling down the statue of Edward Colston, dragged him through the city centre and dumped him in the harbour, near where his ships set sail for West Africa with goods that would be traded for slaves. The statue eventually ended up, in a warehouse covered in mud after having been fished from the water.

This equivalence between statue and body is also a striking feature of recent events, as when the fellers of Colston kneeled on his neck in an echo of the death of George Floyd because of Minneapolis police in United States. In an act of symbolic revenge, a figure who profited from the oppression of Black bodies was subjected to the same violence perpetrated by his $21^{\text {st }}$ century successors. There has been a lot of conversation of the "othering" of people and entire people groups, and how to handle separation and inconsistent treatment of some in the public space.

Massey (1994) explains that the targeting of such monuments operates as a practice of deterritorialization by which fixed and exclusive place identities are destabilized and shifted to a more 'progressive sense of place' based on connections, and interaction with difference. Huyssen (2003) argues that the legacy of specific events or figures that may in some cases be long gone but whose consequences or legacy are still persistent slavery, colonialism, fascism, occupation, and totalitarianism.

The narratives highlighted above, upon analysis show monuments serve as a means of keeping history alive and in instances of racially challenging 
monuments such figures to certain social classes create a sense of bifurcation from other social classes thus creating a sense of "othering". The pulling down of monuments creates a means of amending a troubled history and a way of honoring their ancestors in open defiance of their perceived oppressors.

By challenging this authority, protesters maintain and interfaces minority gatherings' cases for social acknowledgment and for the 'right to equality' as a comprehensive and majority rule.

\section{Conclusion}

This study portrayed various experiences associated with and reasons for the pulling down and defacement of monuments, and as to who participates in Fallist activities, how these intercessions are performed, and how Fallists seek to reshape the past, present and future of society. Narratives of removing and pulling down monuments is evidence that it is not simply about challenging the past but, as a method for political battle for against social inequality, recognition and injustice. It can be perceived that the pulling down of public monuments by the minority, marginalized and/or oppressed civic groups in today's socially, politically and ethnically diverse cities as a means of political struggle for social change. It can also be argued that the form of political attacks on monuments which reinforce racism, oppression, discrimination and intolerance takes place with a view of transforming the society into a place of heterogeneity and equality. The pulling down of monuments is thus not merely about contesting the past; it also operates as a tool for inquiring, critiquing, and subverting the present. In this context, it can be argued that it is not much about the killing of memory, erasing and forgetting the past, but more about unpacking, deconstructing and challenging troubled heritage and opening up for new meaning.

\section{Reference}

Barthes, R. (2001). Mythologies. Original publication 1951. New York: Hill and Wang.

Bevan, R. (2007). The destruction of memory: Architecture at war. Reaktion books.

Bredekamp, H. (2017). Image Acts: a systematic approach to visual agency (Vol. 2). Walter de Gruyter GmbH \& Co KG. 
Chigudu, S. (2020). Rhodes Must Fall in Oxford: a critical testimony. Critical African Studies, 12(3), 302-312.

Gamboni, D. (2013). The destruction of art: iconoclasm and vandalism since the French Revolution. Reaktion books.

Hobsbawn, E. (1983). Introduction: inventing traditions. The invention of tradition, $1-14$.

Huyssen, A. (2003). Present pasts: Urban palimpsests and the politics of memory. Stanford University Press.

Knudsen, B. T., \& Andersen, C. (2019). Affective politics and colonial heritage, Rhodes Must Fall at UCT and Oxford. International Journal of Heritage Studies, 25(3), 239-258.

Latour, B. (2002). What is iconoclash? Or is there a world beyond the image wars. Iconoclash: Beyond the image wars in science, religion, and art, 14-37.

Mitchell, M. N. (2020). 'We always knew it was possible' The long fight against symbols of white supremacy in New Orleans. City, 24(3-4), 580-593.

Macdonald, S. (2010). Difficult heritage: Negotiating the Nazi past in Nuremberg and beyond. Routledge.

Marschall, S. (2017). Targeting statues: monument "Vandalism" as an expression of sociopolitical protest in South Africa. African Studies Review, 60(3), 203-219.

Massey, D. (1994). A Global Sense of Place. Space, Place, and Gender, Minneapolis.

Presciuttini, G. (2017, April 20). Ancient History Encyclopedia. Retrieved from https://www.ancient.eu/sejanus/

Riedlmayer, A. (1995). Erasing the past: The destruction of libraries and archives in Bosnia-Herzegovina. Review of Middle East Studies, 29(1), 7-11.

Shepherd, N. (2020). After the\# fall: The shadow of Cecil Rhodes at the University of Cape Town. City, 24(3-4), 565-579.

Varner, E. R. (2004). Monumenta Graeca et Romana: Mutilation and transformation: damnatio memoriae and Roman imperial portraiture (Vol. 10). Brill.

Wendland, T. (2017). With Lee Statue's Removal, Another Battle of New Orleans Comes to a Close. National Public Radio, 20. 
Notes

i See for further details: Hobsbawm, E., \& Ranger, T. (Eds.). (2012). The invention of tradition. Cambridge University Press

${ }^{\text {ii }}$ Number of black students in Oxford rises, but low numbers admitted to colleges, in: ITV

News, 22 June 2020, https://www.itv.com/news/2020-06-23/number-of-blackstudents-in

-oxford-rises-but-low-numbers-admitted-to-colleges (12.08.2020). 
